\title{
ICAM1 wt Allele
}

National Cancer Institute

\section{Source}

National Cancer Institute. ICAM1 wt Allele. NCI Thesaurus. Code C51155.

Human ICAM1 wild-type allele is located within 19p13.3-p13.2 and is approximately $16 \mathrm{~kb}$ in length. This allele, which encodes intercellular adhesion molecule 1 protein, is involved in accessory adhesion signal transduction and immune interactions. 